\title{
ALD-ZnMgO and absorber surface modifications to substitute CdS buffer layers in co-evaporated CIGSe solar cells
}

\author{
Ramis Hertwig*, Shiro Nishiwaki, Mario Ochoa, Shih-Chi Yang, Thomas Feurer, Evgeniia Gilshtein, \\ Ayodhya N. Tiwari, and Romain Carron \\ Laboratory for Thin Films and Photovoltaics, Empa-Swiss Federal Laboratories for Materials Science and Technology, \\ Ueberlandstrasse 129, 8600 Duebendorf, Switzerland
}

Received: 15 July 2020 / Received in final form: 24 September 2020 / Accepted: 8 December 2020

\begin{abstract}
High efficiency chalcopyrite thin film solar cells generally use chemical bath deposited CdS as buffer layer. The transition to Cd-free buffer layers, ideally by dry deposition methods is required to decrease Cd waste, enable all vacuum processing and circumvent optical parasitic absorption losses. In this study, $\mathrm{Zn}_{1-\mathrm{x}} \mathrm{Mg}_{\mathrm{x}} \mathrm{O}$ thin films were deposited by atomic layer deposition (ALD) as buffer layers on co-evaporated $\mathrm{Cu}(\mathrm{In}, \mathrm{Ga}) \mathrm{Se}_{2}$ (CIGS) absorbers. A specific composition range was identified for a suitable conduction band alignment with the absorber surface. We elucidate the critical role of the CIGS surface preparation prior to the dry ALD process. Wet chemical surface treatments with potassium cyanide, ammonium hydroxide and thiourea prior to buffer layer deposition improved the device performances. Additional in-situ surface reducing treatments conducted immediately prior to $\mathrm{Zn}_{1-\mathrm{x}} \mathrm{Mg}_{\mathrm{x}} \mathrm{O}$ deposition improved device performance and reproducibility. Devices were characterised by (temperature dependant) current-voltage and quantum efficiency measurements with and without light soaking treatment. The highest efficiency was measured to be $18 \%$.
\end{abstract}

Keywords: Thin film solar cells / $\mathrm{Cu}(\mathrm{In}, \mathrm{Ga}) \mathrm{Se}_{2}$ buffer / $\mathrm{ZnMgO} / \mathrm{ALD} /$ surface treatment

\section{Introduction}

Prior to the recent record cells [1], the best performing thin film solar cells with chalcopyrite absorbers $(\mathrm{Cu}(\mathrm{In}, \mathrm{Ga})$ $(\mathrm{S}, \mathrm{Se})_{2}$ ) have employed chemical bath deposited (CDB) CdS as the buffer layer [2-4] over alternative buffer materials or deposition methods [5-7]. CdS shows best performances when bath deposited, and is an inherently limiting material for a buffer layer due to its low band gap (Eg) of $2.4 \mathrm{eV}$ [8] and the associated parasitic absorption. Therefore, industrial manufacturing is hindered by the added complexity of a highly uniform wet deposition step between vacuum deposition steps, the low material yield and the Cd-contaminated waste treatment. The ability to tailor the buffer layer to the absorber in terms of band alignment, transparency or lattice mismatch are increasingly necessary when absorber modifications such as alkali post deposition treatment (PDT) [2,9] or Ag incorporation affect the surface [10-12]. High Eg materials like oxides, sulfides and selenides of In and $\mathrm{Zn}$ are recognized as the most promising material choices, as suggested in reviews discussing the difficulties of substituting CBD-CdS with alternative materials or deposition methods [13-15]. The recent improvements on alternatives to CdS, namely

\footnotetext{
* e-mail: ramis.hertwig@empa.ch
}

$\mathrm{CBD}-\mathrm{Zn}(\mathrm{O}, \mathrm{S})[1]$ and notably the $\mathrm{Zn}_{1-\mathrm{x}} \mathrm{Mg}_{\mathrm{x}} \mathrm{O}$ deposited by dry sputtering method [16], surpass the CBD-CdS buffer layer in terms of device efficiency, which was attributed to increased current, bespoke interface engineering and the consequential reduction of recombination [17].

$\mathrm{Zn}_{1-\mathrm{x}} \mathrm{Mg}_{\mathrm{x}} \mathrm{O}$ is suited as buffer material due to its tuneable bandgap $(3.2 \mathrm{eV}$ for $\mathrm{i}-\mathrm{ZnO}, 3.8 \mathrm{eV}$ for $\mathrm{Zn}_{0.8} \mathrm{Mg}_{0.2} \mathrm{O}, 7.7 \mathrm{eV}$ for $\left.\mathrm{MgO}[18,19]\right)$, and the accompanied change of the conduction band minimum (CBM) position from below the CBM of CIS (i-ZnO) to clearly higher than CGS $[20,21] . \mathrm{Zn}_{1-\mathrm{x}} \mathrm{Mg}_{\mathrm{x}} \mathrm{O}$ has been shown to be a viable buffer in case the conduction band offset $(\mathrm{CBO})$ with the absorber is within $0-0.3 \mathrm{eV}[22,23] . \mathrm{Zn}_{1-\mathrm{x}} \mathrm{Mg}_{\mathrm{x}} \mathrm{O}$ has been implemented as buffer layer in CIGS devices with efficiencies higher than $15 \%$ by sputtering $[16,24]$ or atomic layer deposition (ALD) [25-28]. Sputter deposition directly on the absorber is reported to cause sputter damage $[29,30]$, leading to defective interfaces and $V_{\mathrm{OC}}$ losses due to interface recombination $[31,32]$. This can be mitigated by introducing a thin intermediate layer, or using a soft deposition method, for example ALD or indirect sputtering [16].

Devices with alternative buffer layers are prone to metastabilities [33-36], which can improve the performance after exposure to light, elevated temperatures or a combination of both $[37,38]$. The precise nature of metastable enhancement is still debated and may differ 
depending on the processing methods and materials of devices. The possible causes include presence of detrimental negative charges, for example associated with hydrogen or oxygen [34,37], which become inactive after hole capture holes upon light exposure. Another possibility is an interplay between vacancy complexes at the absorber and the buffer $[35,39,40]$.

This work focuses on the substitution of CBD-CdS with a dry deposited high bandgap material and the effects of surface modifications before the growth of the buffer layer. The approach to prepare the absorber surface is inspired by the chemical environment in a typical CdS-CBD solution prior to CdS growth. First, the properties of the ALD deposited $\mathrm{Zn}_{1-\mathrm{x}} \mathrm{Mg}_{\mathrm{x}} \mathrm{O}$ thin films are analysed in terms of thickness, composition, carrier density, mobility and sheet resistance. This high Eg material allows modification of the conduction band minimum [41,42] in the vicinity of the ones of CIS and CGS [21], which is used to match the conduction band of the absorber. The variation of the $\mathrm{Mg}$ content of the device performance will be discussed. We investigate the influence of different absorber surface treatments before $\mathrm{Zn}_{1-\mathrm{x}} \mathrm{Mg}_{\mathrm{x}} \mathrm{O}$ deposition on the final device properties, notably KCN, ammonia and variants inspired by the successful CdS-CBD deposition process. Absorber dry treatments with trimethylaluminium (TMA) performed in the ALD chamber are also investigated. The effects of wet and dry absorber treatments before the buffer deposition are discussed and resulting cells are compared to CdS-CBD references.

\section{Experimental}

CIGS absorbers were grown on molybdenum-coated soda lime glass by a multistage co-evaporation process at about $450^{\circ} \mathrm{C}$ and were subject to $\mathrm{NaF}$ and $\mathrm{RbF}$ PDT treatment. The growth process is described in [43]. The integrated ratio of $\mathrm{Cu}$ to $\mathrm{In}+\mathrm{Ga}$ (CGI) and $\mathrm{Ga}$ to $\mathrm{In}+\mathrm{Ga}$ (GGI) is 0.96 and 0.40 , respectively, with the GGI near the surface being about 0.3 . Typical gradings can be found in $[43,44]$. As standard treatment, the absorbers were etched in $10 \% \mathrm{w}$ potassium cyanide $(\mathrm{KCN})$ for $3 \mathrm{~min}$, and in $\mathrm{NH}_{4} \mathrm{OH}(2 \mathrm{M}$ $\left[\mathrm{NH}_{3}\right]$ ) aqueous solution for $1 \mathrm{~min}$ with $\mathrm{H}_{2} \mathrm{O}$ rinsing after each step. The transfer time between absorber surface treatments and ALD vacuum was less than $5 \mathrm{~min}$. $\mathrm{ZnMgO}$ was deposited by ALD in a Fiji G2 system (Ultratech). Diethylzinc (DEZ), bis(cyclopentadienyl)magnesium $\left(\mathrm{MgCp}_{2}\right)$, trimethylaluminium (TMA) and $\mathrm{H}_{2} \mathrm{O}(0.06 \mathrm{~s})$ precursors were used at $120^{\circ} \mathrm{C}$ substrate temperature, with Ar carrier gas at a base pressure of $13 \mathrm{~Pa}$. Growth cycles are $\mathrm{ZnO}=\mathrm{H}_{2} \mathrm{O} / \mathrm{N}_{2} / \mathrm{DEZ} / \mathrm{N}_{2}=0.06 / 17 / 0.1 / 5 \mathrm{~s}, \mathrm{MgO}=\mathrm{H}_{2} \mathrm{O} /$ $\mathrm{N}_{2} / \mathrm{MgCp}_{2} / \mathrm{N}_{2}=0.06 / 17 / 2 / 5 \mathrm{~s}, \quad \mathrm{Al}_{2} \mathrm{O}_{3}=\mathrm{H}_{2} \mathrm{O} / \mathrm{N}_{2} / \mathrm{TMA} /$ $\mathrm{N}_{2}=0.06 / 17 / 0.06 / 10 \mathrm{~s}$ for $\mathrm{ZnO}, \mathrm{MgO}$ and $\mathrm{Al}_{2} \mathrm{O}_{3}$, respectively. $\mathrm{MgCp}_{2}$ was heated to $90^{\circ} \mathrm{C}$, the other precursors were kept at room temperature. The stoichiometry of $\mathrm{ZnMgO}$ was varied by the relative numbers of DEZ to $\mathrm{MgCp}_{2}$ pulses, for example a ratio of 9 cycles DEZ $/ \mathrm{H}_{2} \mathrm{O}$ followed by one cycle of $\mathrm{MgCp}_{2} / \mathrm{H}_{2} \mathrm{O}$ were used for $\mathrm{Zn}_{0.9} \mathrm{Mg}_{0.1} \mathrm{O} . \mathrm{Zn}_{1-\mathrm{x}} \mathrm{Mg}_{\mathrm{x}} \mathrm{O}$ thin films were simultaneously deposited on CIGS absorbers, Si (100) and soda-lime glass substrates. Targeted buffer thickness is $28 \mathrm{~nm}$. A similar thickness is used for the CBD-CdS reference sample,

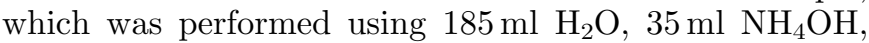
$15 \mathrm{ml} \mathrm{Cd}$-acetate and $15 \mathrm{ml}$ thiourea (TU) for $14 \mathrm{~min}$ at $70^{\circ} \mathrm{C}$. Where specified in the manuscript, solutions containing not all but the same ratio of ingredients as the CdS-CBD were used for surface treatments. The devices are finished with rf-magnetron sputtered $\mathrm{ZnO}$ $(70 \mathrm{~nm})$ and $\mathrm{ZnO}: \mathrm{Al}(200 \mathrm{~nm})$ layers in an $\mathrm{Ar} / \mathrm{O}_{2}$ atmosphere at a pressure of $0.46 \mathrm{~Pa}$ and a power density of 1 and $2.5 \mathrm{~W} \mathrm{~cm}^{-2}$, respectively. $\mathrm{Ni} / \mathrm{Al}$ grid contacts are e-beam deposited $(50 \mathrm{~nm}, 4000 \mathrm{~nm})$. The cell area is defined by mechanical scribing and determined from scans on a flatbed scanner. The cell area for the reference device is $0.512 \mathrm{~cm}^{2}$, for the $\mathrm{Zn}_{1-\mathrm{x}} \mathrm{Mg}_{\mathrm{x}} \mathrm{O}$ buffer devices the area varies around $0.2 \mathrm{~cm}^{2}$.

The ALD buffer layer composition was analysed by X-ray photoelectron spectroscopy (XPS) using a Quantum 2000 photoelectron spectrometer from Physical Electronics with a monochromatic $\mathrm{Al} \mathrm{K \alpha}$ source, operated at a base pressure below $10^{-9} \mathrm{mbar}$. The detailed high-resolution $\mathrm{Mg}$ 2 p peak at $51 \mathrm{eV}$ and $\mathrm{Zn} 2 \mathrm{p}$ peaks at $1022 \mathrm{eV}$ with spin-orbit components splitting of $23 \mathrm{eV}$ were acquired after $10 \mathrm{~s}$ of surface sputtering cycle. Peak spectra were recorded with an energy step size of $0.125 \mathrm{eV}$ and a pass energy of $29.35 \mathrm{eV}$. An ion neutralizer using $\mathrm{Ar}^{+}$of $\approx 1 \mathrm{eV}$ was used to minimize the fluctuations of the binding energy values. The instrument work function was calibrated to give an $\mathrm{Au}$ $4 f_{7 / 2}$ metallic gold binding energy of $84 \mathrm{eV}$. The acquired data were analyzed using PHI MultiPak software. Quantitative analysis was performed by measuring the Mg 2p and Zn 2p peak areas and by applying appropriate relative sensitivity factors (4.431 and 85.057).

The $\mathrm{Zn}_{1-\mathrm{x}} \mathrm{Mg}_{\mathrm{x}} \mathrm{O}$ layer thickness was determined by ellipsometry on a M-2000 device using $\operatorname{Si}(100)$ substrates. Hall measurements were performed using a ECOPIA HMS3000 apparatus with 4 contacts in van der Pauw configuration. I-V characterisation was carried out with a Keithley 2400 source meter and four-terminal contacting under standard test conditions $\left(1000 \mathrm{~W} \mathrm{~m}^{-2}, 298 \mathrm{~K}\right)$ using an ABA type solar simulator on relaxed samples unless stated otherwise. Temperature dependent electrical measurements (TIV and $J_{\mathrm{SC}}$ vs $V_{\mathrm{OC}}$ ) were performed in a cryostat cooled with liquid nitrogen with illumination provided by a halogen lamp with variable intensity filters. External quantum efficiency (EQE) characterisation was performed with a chopped halogen light source, a triplegrating monochromator and a lock-in amplifier at $298 \mathrm{~K}$. A certified monocrystalline Si solar cell was used as reference device for both, EQE and I-V measurements.

\section{Results and discussion}

\section{1 $\mathrm{ZnMgO}$ thin film}

$\mathrm{Zn}_{1-\mathrm{x}} \mathrm{Mg}_{\mathrm{x}} \mathrm{O}$ thin films were deposited on $\mathrm{Si}$ (100) and sodalime glass substrates simultaneously with the deposition on CIGS absorbers. The nominal Mg content (ratio of $\frac{\mathrm{Mg}}{\mathrm{Zn}+\mathrm{Mg}}$ pulses) is approximated from the ratio of $\mathrm{Zn}$ and $\mathrm{Mg}$ pulses, disregarding the intricacies of the ALD deposition process. The Mg content of deposited layers was varied between $5 \%$ 


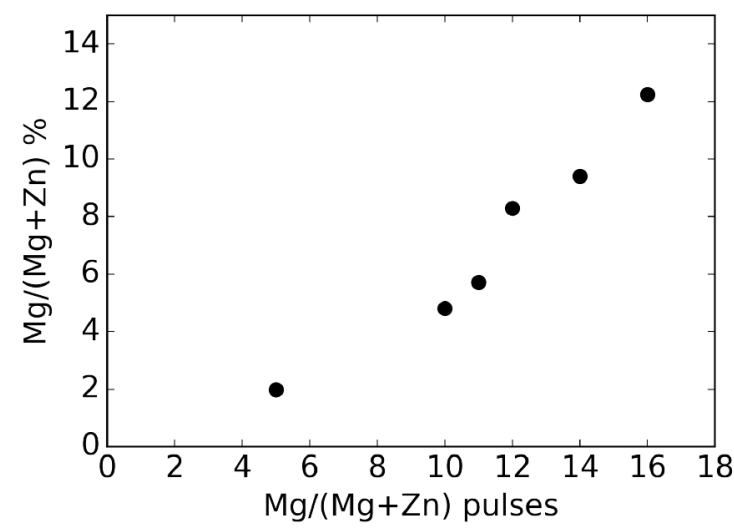

(a)

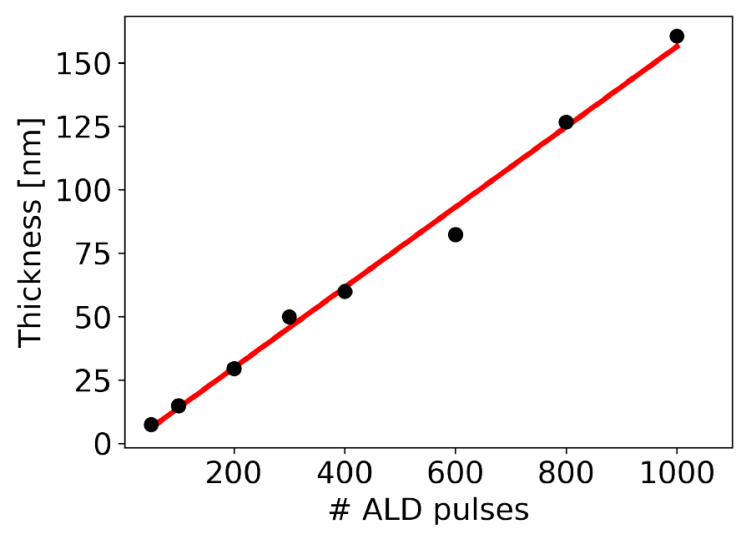

(b)

Fig. 1. (a) $\mathrm{Mg} /(\mathrm{Zn}+\mathrm{Mg})$ content in $\mathrm{Zn}_{1-\mathrm{x}} \mathrm{Mg}_{\mathrm{x}} \mathrm{O}$ films as determined by XPS as function of the nominal value based on the number of pulses. (b) $\mathrm{Zn}_{1-x} \mathrm{Mg}_{\mathrm{x}} \mathrm{O}$ film thickness with number of deposition pulses as determined by ellipsometry. A linear fit (line) results in layer growth of $1.65 \AA$ per pulse.

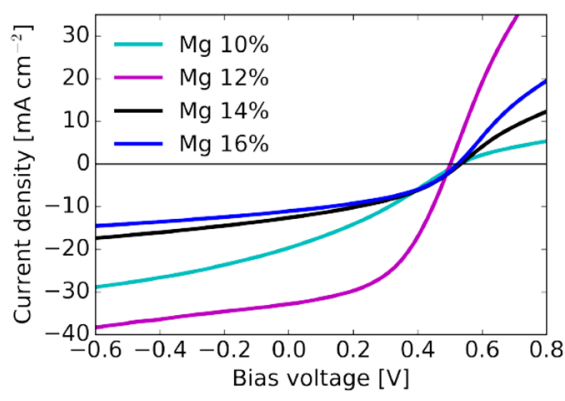

(a)

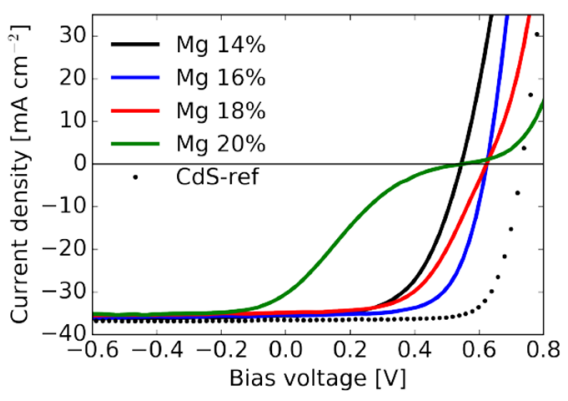

(b)

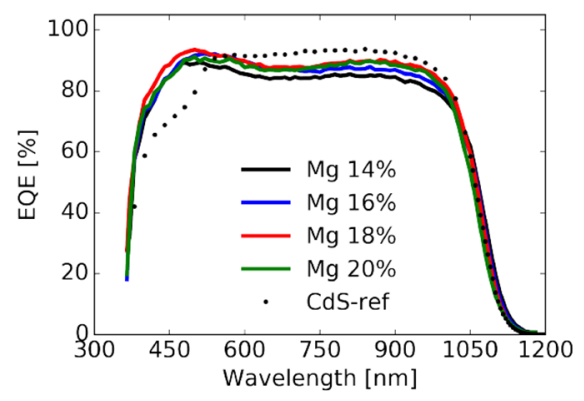

(c)

Fig. 2. (a) IV curves of samples treated with KCN only before buffer deposition. (b) IV curves of samples subjected to KCN and $\mathrm{NH}_{4} \mathrm{OH}$ treatment. (c) EQE of samples with absorbers treated with $\mathrm{KCN}$ and $\mathrm{NH}_{4} \mathrm{OH}$.

and $16 \%$ by adjusting the ratio of $\mathrm{Zn}$ and $\mathrm{Mg}$ pulse numbers, and then analysed by XPS. As shown in Figure 1a, the Mg content determined using XPS does follow the nominal trend, similar to $[25,28] . \mathrm{Zn}_{1-\mathrm{x}} \mathrm{Mg}_{\mathrm{x}} \mathrm{O}$ layers with $\mathrm{Mg}$ content of $16 \%$ deposited on Si substrates show linear growth of $1.65 \AA$ per cycle between 50 and 1000 combined $\mathrm{Zn}$ and $\mathrm{Mg}$ cycles as determined by ellipsometry on $\mathrm{Si}(100)$ wafers, as visible in Figure 1b. Hall measurements could only be acquired with the thickest deposited layer (1000 cycles, $160 \mathrm{~nm}$ ), resulting in a carrier density of $2.7 \times 10^{19} / \mathrm{cm}^{3}$, a mobility of $1.8 \mathrm{~cm}^{2} / \mathrm{Vs}$ and a sheet resistance of $4.96 \times 10^{3} \Omega / s q$, measured on soda lime glass.

\subsection{Influence of $\mathrm{Mg}$ content on device performance}

A conduction band offset of $0-0.3 \mathrm{eV}$ with respect to CIGS $[23,45]$ is targeted by adjusting the $\mathrm{Mg}$ content in the $\mathrm{Zn}_{1-\mathrm{x}} \mathrm{Mg}_{\mathrm{x}} \mathrm{O}$ buffer layer. The CBM of $\mathrm{ZnO}$ is reported equal to that of CIS, whereas the CBM of $\mathrm{CuGaSe}_{2}$ is $0.6-0.7 \mathrm{eV}$ higher [21]. The addition of $\mathrm{Mg}$ in $\mathrm{ZnO}$ increases the CBM and lowers the VBM, which has been shown to result in a better alignment $[22,25,46]$. Considering the band gap variation from $\mathrm{ZnO}$ to $\mathrm{Zn}_{0.8} \mathrm{Mg}_{0.2} \mathrm{O}$ is reported to be $0.6 \mathrm{eV}$ [19], a range of $10 \%$ nominal $\mathrm{Mg}$ content variations is expected to have little influence on device performance. The targeted buffer thickness is $28 \mathrm{~nm}$, which is comparable to the thickness of the CBD-CdS buffer layer. The thickness of the $\mathrm{Zn}_{1-\mathrm{x}} \mathrm{Mg}_{\mathrm{x}} \mathrm{O}$ buffer layer does affect the device performance, but since this can be attributed to an interplay of the buffer with the window layers, this effect is not discussed here [38].

The first absorber series was only rinsed in $\mathrm{KCN}$ before buffer deposition. This treatment cleans the absorber and removes alkali species from the surface as reported in [47]. As depicted in Figure 2a, all devices exhibit poor PV performance for $\mathrm{Mg}$ content between $10 \%$ and $20 \%$, and the $V_{\text {OC }}$ is between 500 and $530 \mathrm{mV}$. There is no obvious correlation of the $\mathrm{PV}$ parameters with the content of $\mathrm{Mg}$ in the buffer layer, see Table 1. As CBD-CdS has been successfully applied to a variety of different absorbers, the hypothesis has been made that the absorber surface is beneficially modified during the initial stages of the 
Table 1. PV parameters of devices with KCN only surface treatment, see Figure 2a. Percentages correspond to the $\mathrm{Mg}$ content of the buffer layer.

\begin{tabular}{lllll}
\hline $2 \times \frac{M g}{Z n+M g}$ & $\begin{array}{l}V_{\mathrm{OC}} \\
(\mathrm{mV})\end{array}$ & $\begin{array}{l}J_{\mathrm{SC}} \\
\left(\mathrm{mA} / \mathrm{cm}^{2}\right)\end{array}$ & $\begin{array}{l}\mathrm{FF} \\
(\%)\end{array}$ & $\begin{array}{l}\eta \\
(\%)\end{array}$ \\
\hline $10 \%$ & 528 & 19.6 & 30 & 3.2 \\
$12 \%$ & 501 & 32.8 & 48 & 8.0 \\
$14 \%$ & 533 & 12.6 & 39 & 2.6 \\
$16 \%$ & 525 & 11.0 & 43 & 2.5 \\
\hline
\end{tabular}

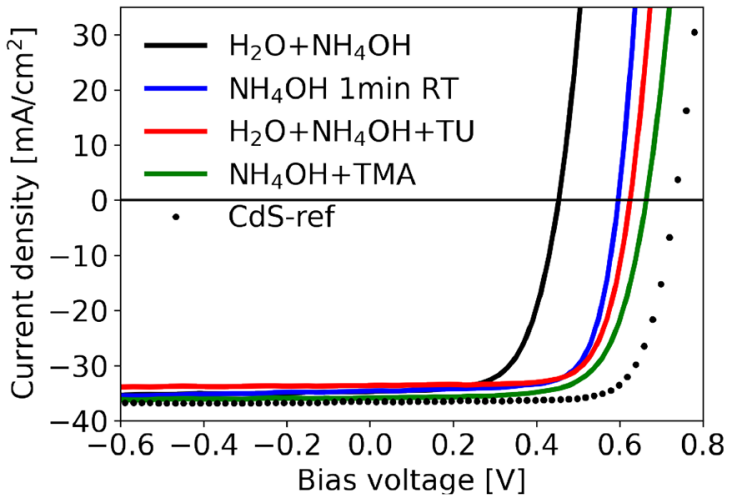

(a)
Table 2. PV parameters of devices with $\mathrm{KCN}$ and $\mathrm{NH}_{4} \mathrm{OH}$ surface treatment, see Figure 2b. Percentages correspond to the $\mathrm{Mg}$ content of the buffer layer.

\begin{tabular}{lllll}
\hline $2 \times \frac{M g}{Z n+M g}$ & $\begin{array}{l}V_{\mathrm{OC}} \\
(\mathrm{mV})\end{array}$ & $\begin{array}{l}J_{\mathrm{SC}} \\
\left(\mathrm{mA} / \mathrm{cm}^{2}\right)\end{array}$ & $\begin{array}{l}\mathrm{FF} \\
(\%)\end{array}$ & $\begin{array}{l}\eta \\
(\%)\end{array}$ \\
\hline $14 \%$ & 545 & 35.6 & 57 & 11.0 \\
$16 \%$ & 624 & 35.5 & 67 & 14.7 \\
$18 \%$ & 623 & 34.8 & 55 & 12.0 \\
$20 \%$ & 547 & 30.2 & 17 & 3.0 \\
\hline
\end{tabular}

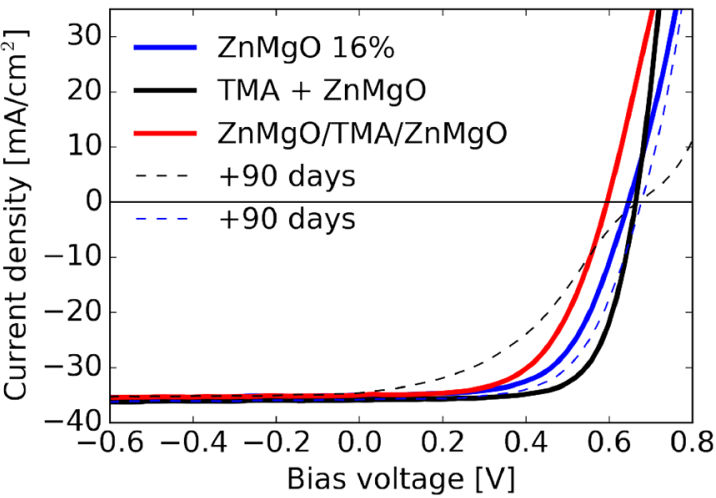

(b)

Fig. 3. (a) Effect of wet treatment before buffer deposition on JV curves. Absorber treatments with $\mathrm{NH}_{4} \mathrm{OH}$ or thiourea-ammonia solution show increased $V_{\mathrm{OC}}$. Additional (b) Influence of a single TMA pulse before and during buffer deposition, with unchanged total $\mathrm{ZnMgO}$ thickness. TMA before $\mathrm{Zn}_{1-\mathrm{x}} \mathrm{Mg}_{\mathrm{x}} \mathrm{O}$ increases $V_{\mathrm{OC}}$ and reduces ageing. TMA during $\mathrm{Zn}_{1-\mathrm{x}} \mathrm{Mg}_{\mathrm{x}} \mathrm{O}$ reduces $V_{\mathrm{OC}}$.

deposition process [48,49]. This leads to the assumption, that a surface modification of the absorber which takes place during the initial stages of CdS-CBD is missing.

The following analysis investigates the effect of a treatment in a solution containing some, but not all ingredients of the CdS-CBD solution in the same ratio, for example, $\mathrm{H}_{2} \mathrm{O}, \mathrm{NH}_{4} \mathrm{OH}$ and $\mathrm{TU}$. After being cleaned in $\mathrm{KCN}$ and rinsed with $\mathrm{H}_{2} \mathrm{O}$, the absorbers were immersed in $\mathrm{NH}_{4} \mathrm{OH}$ for $1 \mathrm{~min}$. As shown in Figure 2b, a clear improvement in $V_{\mathrm{OC}}$ and $\mathrm{FF}$ is observed for $\mathrm{Zn}_{1-\mathrm{x}} \mathrm{Mg} \mathrm{g}_{\mathrm{x}} \mathrm{O}$ buffer layers with $\mathrm{Mg}$ content from $14 \%$ to $20 \%$, with $16 \%$ $\mathrm{Mg}$ resulting in the best device performance, listed in Table 2. Devices with lower Mg content in the buffer layer exhibit lower $V_{\text {OC }}$, while higher $\mathrm{Mg}$ content show a loss in FF, similarly as reported in $[23,25,45,50]$. This can be attributed to the formation of a cliff-like band alignment for low $\mathrm{Mg}$ content, which increases recombination and therefore reduces $V_{\mathrm{OC}}$. High $\mathrm{Mg}$ content raises the $\mathrm{CB}$ of the buffer layer to form a spike-like conduction band offset, which results in a blocking of photocurrent. It should be noted that variations in nominal $\mathrm{Mg}$ content of $2 \%$ already show drastic variations in device performance, narrower than the expected process window of about $10 \%$ nominal $\mathrm{Mg}$ content. In analogy to [51], a non-uniform composition over the very first monolayers could be speculated, which could lead to the formation of a blocking barrier.
The performance of the devices is not as good as the $\mathrm{CdS}$ reference, which is mostly due to the lower $V_{\mathrm{OC}}$ and $\mathrm{FF}$. The small deficit in $J_{\mathrm{SC}}$ is attributed to reflection losses arising from non optimised layer thicknesses and comparatively larger grid shading. Analysis of the EQE curves reveals a potential for $J_{\mathrm{SC}}$ gain arising from the wider buffer bandgap of about $1.1 \mathrm{~mA} / \mathrm{cm}^{2}$ in the range of $360-550 \mathrm{~nm}$ (see Fig. 2c). The absorber bandgap extracted from EQE using Tauc fit procedure is $1.14 \mathrm{eV}$. The following sections will focus on the improvements of $V_{\mathrm{OC}}$ and $\mathrm{FF}$ for buffer layers with $16 \% \mathrm{Mg}$ content.

\subsection{Absorber surface treatments}

As shown before, samples treated with $\mathrm{KCN}$ and $\mathrm{NH}_{4} \mathrm{OH}$ show an increase in $V_{\mathrm{OC}}$ and $\mathrm{FF}$ compared to samples which were etched only with KCN. The improvement can be attributed to a beneficial surface modification during the $\mathrm{NH}_{4} \mathrm{OH}$ treatment. To investigate the analogies of $\mathrm{KCN}$ and $\mathrm{NH}_{4} \mathrm{OH}$ surface treatments with the surface modifications during CdS-CBD, wet treatments of 1 min have been conducted with solutions resembling parts of the CdSCBD process. The solutions used are $\mathrm{H}_{2} \mathrm{O}+\mathrm{NH}_{4} \mathrm{OH}$, $\mathrm{NH}_{4} \mathrm{OH}, \mathrm{H}_{2} \mathrm{O}+\mathrm{NH}_{4} \mathrm{OH}+\mathrm{TU}$. Devices that have been treated with $\mathrm{H}_{2} \mathrm{O}+\mathrm{NH}_{4} \mathrm{OH}$ show a reduction in $V_{\text {OC }}$ with $453 \mathrm{mV}$ (FF 64\%), see Figure 3a. The absorber treated with 
Table 3. PV parameters of devices with $\mathrm{KCN}$ and CBDCdS alike surface treatment, see Figures $3 \mathrm{a}$ and $3 \mathrm{~b}$. All devices have buffer layers of ALD deposited $\mathrm{Zn}_{0.8} 4 \mathrm{Mg}_{0.16} \mathrm{O}$, $28 \mathrm{~nm}$.

\begin{tabular}{lllll}
\hline $2 \times \frac{M g}{Z n+M g}$ & $\begin{array}{l}V_{\mathrm{OC}} \\
(\mathrm{mV})\end{array}$ & $\begin{array}{l}J_{\mathrm{SC}} \\
\left(\mathrm{mA} / \mathrm{cm}^{2}\right)\end{array}$ & $\begin{array}{l}\mathrm{FF} \\
(\%)\end{array}$ & $\begin{array}{l}\eta \\
(\%)\end{array}$ \\
\hline $\mathrm{H}_{2} \mathrm{O}+\mathrm{NH}_{4} \mathrm{OH}$ & 453 & 34.7 & 64 & 10.0 \\
$\mathrm{NH}_{4} \mathrm{OH}$ & 596 & 34.6 & 73 & 15.1 \\
$\mathrm{H}_{2} \mathrm{O}+\mathrm{NH}_{4} \mathrm{OH}+\mathrm{TU}$ & 625 & 33.61 & 73 & 15.3 \\
$\mathrm{NH}_{4} \mathrm{OH}+\mathrm{TMA}$ & 663 & 35.9 & 69 & 16.5 \\
\hline
\end{tabular}

$28 \% \mathrm{NH}_{4} \mathrm{OH}$ solution shows a significantly increased $V_{\mathrm{OC}}$ of $597 \mathrm{mV}$ (FF 73\%). Solutions containing TU and $\mathrm{NH}_{4} \mathrm{OH}$ result in increases in $V_{\mathrm{OC}}$ to $625 \mathrm{mV}$ (FF $73 \%$ ) over pure $\mathrm{NH}_{4} \mathrm{OH}$, which is tentatively attributed to $\mathrm{S}$ incorporation and the consequential higher carrier density of the absorber surface and shorter depletion region as reported in [52-54].

Even with $\mathrm{TU}$ and $\mathrm{NH}_{4} \mathrm{OH}$ treatments, the best achieved $V_{\mathrm{OC}}$ and $\mathrm{FF}$ are significantly lower than the CdS reference sample, as reported in Table 3. To further treat the absorber surface, TMA was pulsed once in the ALD chamber before buffer deposition. The resulting $V_{\mathrm{OC}}$ of $664 \mathrm{mV}$ (FF $69 \%$ ) yield a device efficiency of $16.5 \%$ without light and or heat soaking, as listed in Table 4. No further change in device performance was observed when repeating TMA pulses prior to $\mathrm{Zn}_{1-\mathrm{x}} \mathrm{Mg}_{\mathrm{x}} \mathrm{O}$ deposition, similarly as reported in [55]. Hence, the improvement by a single pulse of TMA can be attributed to further etching of the absorber surface, formation of local $\mathrm{Al}_{2} \mathrm{O}_{3}$ islands with passivating effect, or a chemical reduction of surface species [56]. Another possibility which needs to be addressed is the potential doping of $\mathrm{Zn}_{1-\mathrm{x}} \mathrm{Mg}_{\mathrm{x}} \mathrm{O}$ with $\mathrm{Al}$ and the corresponding change in carrier density [57]. The improvement in $V_{\mathrm{OC}}$ is unlikely the result of a further increase in the CBM. ZnMgO:Al has a higher $\mathrm{CB}$ and lower VB than $\mathrm{ZnMgO}$, hence it can be seen as a strong substitute for $\mathrm{Mg}$. The introduction of $\mathrm{Al}$ will change the composition relative to the pulse ratio, which is one pulse of $\mathrm{Al}$ in 198 total pulses or roughly $0.5 \%$. This would represent a $\mathrm{ZnMgO}: \mathrm{Al}$ which is expected to behave like a $\mathrm{ZnMgO}$ with more than $16 \%$ $\mathrm{Mg}$ content, which are shown to have lower FF and not higher $V_{\mathrm{OC}}$, see Figure $3 \mathrm{~b}$. For comparison, TMA was also pulsed halfway through the $\mathrm{Zn}_{1-\mathrm{x}} \mathrm{Mg}_{\mathrm{x}} \mathrm{O}$ deposition and directly compared to a device where TMA was pulsed at the very beginning, see Figure $3 \mathrm{~b}$. If $\mathrm{Al}$ distributes evenly in $\mathrm{Zn}_{1-\mathrm{x}} \mathrm{Mg}_{\mathrm{x}} \mathrm{O}$ as reported in [58], the expected outcome would be the same. The device where TMA is pulsed in the middle of the buffer deposition exhibits a lower $V_{\mathrm{OC}}$ and FF, which indicates absorber surface treatment instead of modification of the buffer layer. In case the single TMA pulse during the buffer deposition creates a uniform blocking layer, the charge carriers are able to tunnel through. The improvement of pulsing TMA at the beginning of the buffer deposition are primary in $\mathrm{FF}$ $(61-69 \%)$ and secondary in $V_{\mathrm{OC}}(647-664 \mathrm{eV})$, which support the hypothesis of a surface treatment further. In addition, the beneficial effect of TMA extends to a reduction in aging of the device. Devices without TMA
Table 4. PV parameters of best devices with single TMA pulse during buffer deposition. "B" refers to a single cycle of TMA before buffer deposition, "M" refers to a single TMA pulse midway during buffer deposition.

\begin{tabular}{lllll}
\hline $2 \times \frac{M g}{Z n+M g}$ & $\begin{array}{l}V_{\mathrm{OC}} \\
(\mathrm{mV})\end{array}$ & $\begin{array}{l}J_{\mathrm{SC}} \\
\left(\mathrm{mA} / \mathrm{cm}^{2}\right)\end{array}$ & $\begin{array}{l}\mathrm{FF} \\
(\%)\end{array}$ & $\begin{array}{l}\eta \\
(\%)\end{array}$ \\
\hline $\mathrm{B}$ & 663 & 35.9 & 69 & 16.5 \\
$\mathrm{~B}(+90$ days $)$ & 677 & 35.8 & 62 & 15.0 \\
$\mathrm{M}$ & 594 & 35.0 & 58 & 12.2 \\
$\mathrm{M}(+90$ days $)$ & 668 & 34.5 & 42 & 9.6 \\
\hline
\end{tabular}

Table 5. PV parameters of best performing device before and after light soaking at 1 sun, measured 90 days after finishing the cell.

\begin{tabular}{lllll}
\hline Duration & $\begin{array}{l}V_{\mathrm{OC}} \\
(\mathrm{mV})\end{array}$ & $\begin{array}{l}J_{\mathrm{SC}} \\
\left(\mathrm{mA} / \mathrm{cm}^{2}\right)\end{array}$ & $\begin{array}{l}\mathrm{FF} \\
(\%)\end{array}$ & $\begin{array}{l}\eta \\
(\%)\end{array}$ \\
\hline-90 days & 663 & 35.9 & 69 & 16.5 \\
0 min & 677 & 35.8 & 62 & 15.0 \\
$2 \mathrm{~min}$ & 679 & 35.9 & 65 & 15.9 \\
$45 \mathrm{~min}$ & 689 & 35.9 & 70 & 17.5 \\
$390 \mathrm{~min}$ & 693 & 35.9 & 72 & 18.0 \\
\hline
\end{tabular}

display a loss in FF from $61 \%$ to $41 \%$ over 3 months storage in ambient conditions, as compared to $69-62 \%$ with TMA (Tab. 5).

\subsection{Metastabilites and interface recombination}

The presented devices with $\mathrm{Zn}_{1-\mathrm{x}} \mathrm{Mg}_{\mathrm{x}} \mathrm{O}$ buffer show a reversible light soaking effect. The evolution of the IV curve for the best performing device with $\mathrm{Zn}_{1-\mathrm{x}} \mathrm{Mg}_{\mathrm{x}} \mathrm{O}$ buffer device is presented in Figure 4a. The FF increases from $61 \%$ to $65 \%$ already after 2 min (1 sun illumination). Light exposure of $45 \mathrm{~min}$ increases the $\mathrm{FF}$ to $71 \%$, accompanied by an increase in $V_{\mathrm{OC}}$ from 679 to $689 \mathrm{mV}$, resulting in $17.5 \%$ efficiency. Further light soaking up to $390 \mathrm{~min}$ improves $\mathrm{FF}$ to $72 \%, V_{\mathrm{OC}} 693 \mathrm{mV}$ and $18 \%$ efficiency. Similar effects have been reported by others for $\mathrm{Zn}_{1-\mathrm{x}} \mathrm{Mg}_{\mathrm{x}} \mathrm{O}$ and other materials [28,32,59] (Fig. 4).

Different mechanisms can decrease the $V_{\mathrm{OC}}$, for example increased interface recombination, reduction in carrier lifetimes at the interface [60,61], change in doping level of the absorber surface due to inter-diffusion [26,48], or photocurrent blocking barriers [32,59]. We can exclude inappropriate conduction band offsets as the $\mathrm{Mg}$ content in the buffer layer was systematically investigated (see Sect. 3.2).

In order to assess the interface quality, the best $\mathrm{Zn}_{1-\mathrm{x}} \mathrm{Mg}_{\mathrm{x}} \mathrm{O}$ buffer device and the corresponding CdS reference device have been analysed with temperature dependant $J_{\mathrm{SC}}-V_{\mathrm{OC}}$ measurements at different light intensities. The $\mathrm{Zn}_{1-\mathrm{x}} \mathrm{Mg}_{\mathrm{x}} \mathrm{O}$ buffer device has been 


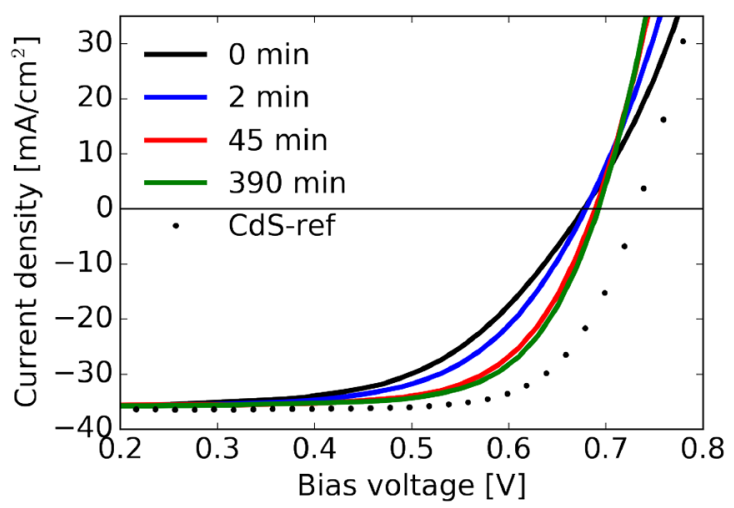

(a)

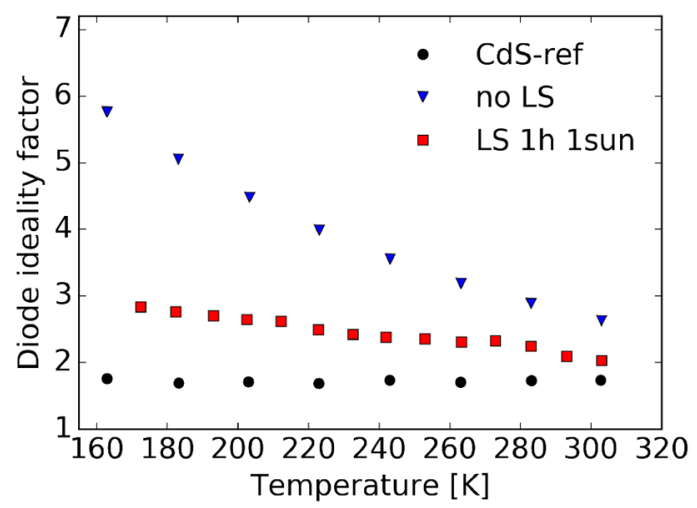

(b)

Fig. 4. (a) IV of $\mathrm{Zn}_{1-\mathrm{x}} \mathrm{Mg}_{\mathrm{x}} \mathrm{O}$ buffer device before and after different light soaking duration at 1 sun. (b) Ideality factor extracted from $J_{\mathrm{SC}}-V_{\mathrm{OC}}$ measurements for CdS reference (circle) and $\mathrm{Zn}_{1-\mathrm{x}} \mathrm{Mg}_{\mathrm{x}} \mathrm{O}$ buffer device before (triangle) and after light soaking (square).

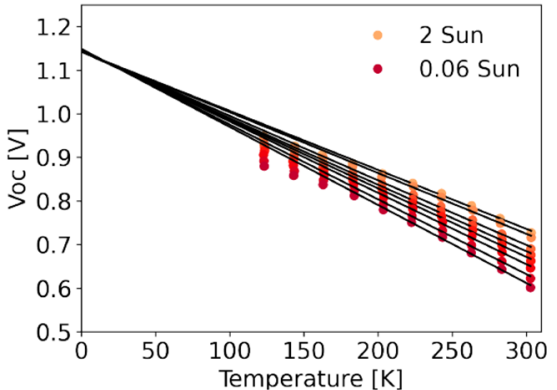

(a)

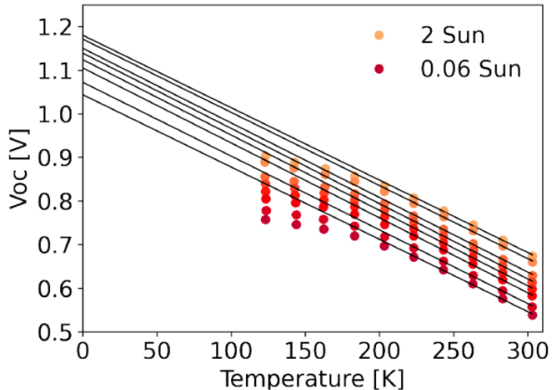

(b)

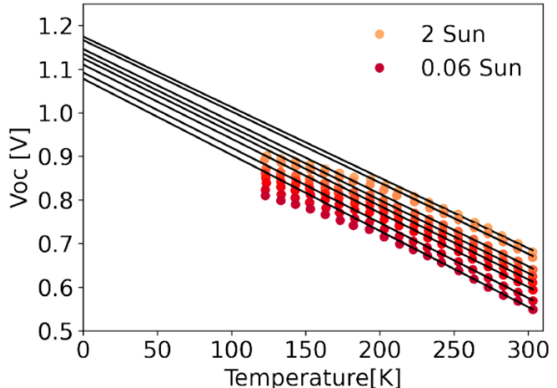

(c)

Fig. 5. Extrapolation of $V_{\mathrm{OC}}$ at $0 \mathrm{~K}$ for (a) CdS reference, (b) $\mathrm{Zn}_{1-\mathrm{x}} \mathrm{Mg}_{\mathrm{x}} \mathrm{O}$ buffer (c) $\mathrm{Zn}_{1-\mathrm{x}} \mathrm{Mg}_{\mathrm{x}} \mathrm{O}$ buffer after light soaking for $1 \mathrm{~h}$ at 1 sun.

analysed before and after light soaking at 1 sun for $1 \mathrm{~h}$. The respective diode quality factor $\mathrm{A}$ is presented in Figure $4 \mathrm{~b}$, the extrapolation of $V_{\mathrm{OC}}$ at $0 \mathrm{~K}$ is presented in Figure 5 . For the reference device, the ideality factor $\mathrm{A}$ is about 1.7 and almost insensitive to temperature. A pronounced difference before and after light soaking of the $\mathrm{Zn}_{1-\mathrm{x}} \mathrm{Mg} \mathrm{g}_{\mathrm{x}} \mathrm{O}$ buffer device is visible in the respective diode ideality factors $\mathrm{A}$. The relaxed $\mathrm{Zn}_{1-\mathrm{x}} \mathrm{Mg}_{\mathrm{x}} \mathrm{O}$ buffer device shows $\mathrm{A}$ increase from 3.0 to 5.9 with decreasing temperature. After exposure to 1 sun, the ideality factor is still higher than 2, but the range has been limited to 2.1-2.9. The temperature dependence of the ideality factor of the $\mathrm{Zn}_{1-\mathrm{x}} \mathrm{Mg}_{\mathrm{x}} \mathrm{O}$ buffer devices is probably linked to fluctuations in the activation energy of the dominating recombination process [62]. The fluctuation is reduced during light soaking, which is evident from the decreased values for A, but not fully eliminated.

The $V_{\mathrm{OC}}$ at $0 \mathrm{~K}$ before and after light soaking is extrapolated for the temperatures from 200 to $300 \mathrm{~K}$. The reference device shows an extrapolated $V_{\mathrm{OC}}$ at $0 \mathrm{~K}$ between 1.14 and $1.15 \mathrm{eV}$, in good agreement with the bandgap of $1.14 \mathrm{eV}$ extracted from the EQE curve using the Tauc fit method (Fig. 2). The device with $\mathrm{Zn}_{1-\mathrm{x}} \mathrm{Mg}_{\mathrm{x}} \mathrm{O}$ buffer layer shows a spread in extrapolated $V_{\mathrm{OC}}$ at $0 \mathrm{~K}$ from $1.18 \mathrm{eV}$ down to $1.05 \mathrm{eV}$ before light soaking, and ranges from 1.18 to $1.08 \mathrm{eV}$ after light soaking ( $1 \mathrm{~h}$ at $1 \mathrm{sun})$. The decreased extrapolated $V_{\mathrm{OC}}$ values suggest a dominant recombination path located at the absorber buffer interface [62] possibly mediated by a defect within the bandgap. Such an effect can also explain the reduced $V_{\mathrm{OC}}$. Improved $\mathrm{FF}$ and $V_{\mathrm{OC}}$ due to the absence of shunts and a slight increase in device $V_{\mathrm{OC}}$ are consistent with the IV analysis for different light soaking durations presented in Figure 4a.

\section{Conclusion}

CIGS solar devices with ALD ZnMgO buffer layers were fabricated with efficiencies reaching $18 \%$ after light soaking. The conduction band alignment was investigated by systematically varying the $\mathrm{Zn}_{1-\mathrm{x}} \mathrm{Mg}_{\mathrm{x}} \mathrm{O}$ stoichiometry, revealing a best alignment with $\mathrm{x}=0.16$ composition. The compositional range for suitable band alignment with CIGS is found more narrow than expected. The treatments performed to investigate the effect on the absorber surface were performed immediately prior to buffer deposition. Wet treatments using $\mathrm{NH}_{4} \mathrm{OH}$, thiourea or both resulted in improvements of $V_{\mathrm{OC}}$ and FF. Additional improvements were achieved by a single TMA pulse in vacuum, before the $\mathrm{Zn}_{1-\mathrm{x}} \mathrm{Mg}_{\mathrm{x}} \mathrm{O}$ buffer deposition, which we assign to reduction 
of surface species and subsequent chemical surface passivation. The best results were achieved by a combination of wet etching in $\mathrm{KCN}$ and $\mathrm{NH}_{4} \mathrm{OH}$ before exposure with TMA under vacuum. The $\mathrm{Zn}_{1-\mathrm{x}} \mathrm{Mg}_{\mathrm{x}} \mathrm{O}$ devices exhibit a reversible metastable light soaking effect, improving the device efficiency. Temperature and illumination dependant electrical characterization revealed increased interface recombination in $\mathrm{Zn}_{1-\mathrm{x}} \mathrm{Mg}_{\mathrm{x}} \mathrm{O}$ buffer devices, as compared to the $\mathrm{CdS}$ reference. We consider $\mathrm{Zn}_{1-\mathrm{x}} \mathrm{Mg}_{\mathrm{x}} \mathrm{O}$ as a possible alternative buffer layer for CIGS solar cells, although further work is necessary to understand and overcome the unwanted recombination mechanisms and improve cell efficiencies.

This work was partially supported by the Swiss Federal Office of Energy (contract Nr SI/501614-01 ImproCIS) and from the Swiss State Secretary for Education, Research and Innovation (SERI) under contract number 17.00105 (EMPIR project HyMet). The EMPIR programme is co-financed by the participating states and by the European Union's Horizon 2020 research and innovation programme under the Marie Skłodowska-Curie grant agreement number 754364 .

\section{Author contribution statement}

R.H. conceived the idea, which was co-developed with R.C., M.O. and A.N.T. S.N. deposited the absorbers. R.H. performed device fabrication after absorber deposition, characterization of thin films and devices. E.G. conducted the XPS measurements and analysis. All authors were involved in the interpretation of the data. R.H wrote the manuscript. All authors provided feedback and corrections to the manuscript.

\section{References}

1. M. Nakamura, K. Yamaguchi, Y. Kimoto, Y. Yasaki, T. Kato, H. Sugimoto, IEEE J. Photovolt. 9, 1863 (2019)

2. A. Chirilă, P. Reinhard, F. Pianezzi, P. Bloesch, A.R. Uhl, C. Fella, L. Kranz, D. Keller, C. Gretener, H. Hagendorfer et al., Nat. Mater. 12, 1107 (2013)

3. P. Jackson, R. Wuerz, D. Hariskos, E. Lotter, W. Witte, M. Powalla, Phys. Status Solidi (RRL) - Rapid Res. Lett. 10, $583(2016)$

4. T. Kato, J.L. Wu, Y. Hirai, H. Sugimoto, V. Bermudez, IEEE J. Photovolt. 9, 325 (2019)

5. J. Lindahl, J. Keller, O. Donzel-Gargand, P. Szaniawski, M. Edoff, T. Törndahl, Sol. Energy Mater. Sol. Cells 144, 684 (2016)

6. F. Larsson, O. Donzel-Gargand, J. Keller, M. Edoff, T. Törndahl, Sol. Energy Mater. Sol. Cells 183, 8 (2018)

7. J. Löckinger, S. Nishiwaki, C. Andres, R. Erni, M.D. Rossell, Y.E. Romanyuk, S. Buecheler, A.N. Tiwari, ACS Appl. Mater. Interfaces 10, 43603 (2018)

8. S. Prabahar, M. Dhanam, J. Cryst. Growth 285, 41 (2005)

9. F. Pianezzi, P. Reinhard, A. Chirilă, B. Bissig, S. Nishiwaki, S. Buecheler, A.N. Tiwari, Phys. Chem. Chem. Phys. 16, 8843 (2014)

10. O. Donzel-Gargand, F. Larsson, T. Törndahl, L. Stolt, M. Edoff, Prog. Photovolt. Res. Appl. 27, 220 (2019)
11. H. Simchi, B.E. McCandless, K. Kim, J.H. Boyle, R.W. Birkmire, W.N. Shafarman, IEEE J. Photovolt. 2, 519 (2012)

12. N.H. Valdes, K.J. Jones, R.L. Opila, W.N. Shafarman, IEEE J. Photovolt. 9, 1846 (2019)

13. D. Hariskos, S. Spiering, M. Powalla, Thin Solid Films 480-481, 99 (2005)

14. S. Siebentritt, Solar Energy 77, 767 (2004)

15. N. Naghavi, D. Abou-Ras, N. Allsop, N. Barreau, S. Bücheler, A. Ennaoui, C.H. Fischer, C. Guillen, D. Hariskos, J. Herrero et al., Prog. Photovolt. Res. Appl. 18, 411 (2010)

16. J. Chantana, Y. Kawano, T. Nishimura, Y. Kimoto, T. Kato, H. Sugimoto, T. Minemoto, Prog. Photovolt. Res. Appl., pip. 28, $79(2020)$

17. J. Chantana, Y. Kawano, T. Nishimura, Y. Kimoto, T. Kato, H. Sugimoto, T. Minemoto, ACS Appl. Energy Mater. 3, $1292(2020)$

18. O. Taurian, M. Springborg, N. Christensen, Solid State Commun. 55, 351 (1985)

19. Ü. Özgür, Y.I. Alivov, C. Liu, A. Teke, M. Reshchikov, S. Dogan, V. Avrutin, S.J. Cho, H. Morkoç, J. Appl. Phys. 98, $11(2005)$

20. C. Kılıç, A. Zunger, Appl. Phys. Lett. 81, 73 (2002)

21. A. Klein, J. Phys.: Condens. Matter 27, 134201 (2015)

22. T. Minemoto, Y. Hashimoto, T. Satoh, T. Negami, H. Takakura, Y. Hamakawa, J. Appl. Phys. 89, 8327 (2001)

23. M. Murata, J. Chantana, N. Ashida, D. Hironiwa, T. Minemoto, Japanese J. Appl. Phys. 54, 032301 (2015)

24. Y. Kuwahata, T. Minemoto, Renew. Energy 65, 113 (2014)

25. T. Törndahl, C. Platzer-Björkman, J. Kessler, M. Edoff, Prog. Photovolt. Res. Appl. 15, 225 (2006)

26. C.-S. Lee, S. Kim, E.A. Al-Ammar, H. Kwon, B.T. Ahn, ECS J. Solid State Sci. Technol. 3, Q99 (2014)

27. J. Pettersson, C. Platzer-Björkman, M. Edoff, Prog. Photovolt. Res. Appl. 17, 460 (2009)

28. S. Kim, C.S. Lee, S. Kim, R. Chalapathy, E.A. Al-Ammar, B. T. Ahn, Phys. Chem. Chem. Phys. 17, 19222 (2015)

29. T. Minemoto, J. Julayhi, Curr. Appl. Phys. 13, 103 (2013)

30. M. Sugiyama, H. Sakakura, S.W. Chang, Electrochim. Acta 131, 236 (2014)

31. J. Chantana, T. Kato, H. Sugimoto, T. Minemoto, Prog. Photovolt. Res. Appl. 26, 127 (2018)

32. J. Löckinger, S. Nishiwaki, T.P. Weiss, B. Bissig, Y.E. Romanyuk, S. Buecheler, A.N. Tiwari, Sol. Energy Mater. Sol. Cells 174, 379 (2017)

33. J. Serhan, Z. Djebbour, W. Favre, A. Migan-Dubois, A. Darga, D. Mencaraglia, N. Naghavi, G. Renou, J.F. Guillemoles, D. Lincot, Thin Solid Films 519, 7606 (2011)

34. N. Naghavi, S. Temgoua, T. Hildebrandt, J.F. Guillemoles, D. Lincot, Prog. Photovolt. Res. Appl. 23, 1820 (2015)

35. T. Lavrenko, T. Walter, B. Plesz, Phys. Status Solidi C 14, 1600197 (2017)

36. I. Repins, S. Glynn, T.J. Silverman, R. Garris, K. Bowers, B. Stevens, L. Mansfield, Prog. Photovolt. Res. Appl. 27, 749 (2019)

37. J. Serhan, Z. Djebbour, A. Darga, D. Mencaraglia, N. Naghavi, G. Renou, D. Lincot, J.F. Guillemeoles, Sol. Energy Mater. Sol. Cells 94, 1884 (2010)

38. N. Naghavi, G. Renou, V. Bockelee, F. Donsanti, P. Genevee, M. Jubault, J. Guillemoles, D. Lincot, Thin Solid Films 519, $7600(2011)$

39. S. Lany, A. Zunger, J. Appl. Phys. 100, 113725 (2006) 
40. S. Lany, A. Zunger, Phys. Rev. Lett. 100, 016401 (2008)

41. W.S. Choi, J.G. Yoon, Solid State Commun. 152, 345 (2012)

42. F. Troni, G. Sozzi, R. Menozzi, A numerical study of the design of $\mathrm{ZnMgO}$ window layer for Cadmium-free thin-film CIGS solar cells, in 2011 7th Conference on Ph. D. Research in Microelectronics and Electronics (IEEE, 2011), pp. 193-196

43. R. Carron, S. Nishiwaki, T. Feurer, R. Hertwig, E. Avancini, J. Löckinger, S.C. Yang, S. Buecheler, A.N. Tiwari, Adv. Energy Mater. 9, 1900408 (2019)

44. B. Bissig, R. Carron, L. Greuter, S. Nishiwaki, E. Avancini, C. Andres, T. Feurer, S. Buecheler, A.N. Tiwari, Prog. Photovolt. Res. Appl. 26, 894 (2018)

45. T. Minemoto, T. Matsui, H. Takakura, Y. Hamakawa, T. Negami, Y. Hashimoto, T. Uenoyama, M. Kitagawa, Sol. Energy Mater. Sol. Cells 67, 83 (2001)

46. C.S. Lee, Y.M. Shin, B.T. Ahn, ECS Trans. 41, 213 (2011)

47. E. Avancini, R. Carron, T.P. Weiss, C. Andres, M. Bürki, C. Schreiner, R. Figi, Y.E. Romanyuk, S. Buecheler, A.N. Tiwari, Chem. Mater. 29, 9695 (2017)

48. T. Nakada, A. Kunioka, Appl. Phys. Lett. 74, 2444 (1999)

49. T.M. Friedlmeier, P. Jackson, D. Kreikemeyer-Lorenzo, D. Hauschild, O. Kiowski, D. Hariskos, L. Weinhardt, C. Heske, M. Powalla, A closer look at initial CdS growth on highefficiency $\mathrm{Cu}(\mathrm{In}, \mathrm{Ga}) \mathrm{Se}_{2}$ absorbers using surface-sensitive methods, in 2016 IEEE 43rd Photovoltaic Specialists Conference (PVSC), (IEEE, 2016), pp. 0457-0461

50. C. Platzer-Björkman, T. Törndahl, A. Hultqvist, J. Kessler, M. Edoff, Thin Solid Films 515, 6024 (2007)
51. F. Larsson, L. Stolt, A. Hultqvist, M. Edoff, J. Keller, T. Törndahl, ACS Appl. Energy Mater. 3, 7208 (2020)

52. T. Nakada, H. Ohbo, T. Watanabe, H. Nakazawa, M. Matsui, A. Kunioka, Sol. Energy Mater. Sol. Cells 49, 285 (1997)

53. K. Nakada, M. Watanabe, T. Nishimura, N. Suyama, A. Yamada, Japanese J. Appl. Phys. 59, 031005 (2020)

54. W. Witte, D. Hariskos, M. Powalla, Thin Solid Films 519, 7549 (2011)

55. J. Keller, F. Gustavsson, L. Stolt, M. Edoff, T. Törndahl, Sol. Energy Mater. Sol. Cells 159, 189 (2017)

56. P. Alen, M. Juppo, M. Ritala, T. Sajavaara, J. Keinonen, M. Leskelä, J. Electrochem. Soc. 148, G566 (2001)

57. K. Koike, K. Hama, I. Nakashima, S. Sasa, M. Inoue, M. Yano, Japanese J. Appl. Phys. 44, 3822 (2005)

58. G. Luka, L. Wachnicki, B.S. Witkowski, T.A. Krajewski, R. Jakiela, E. Guziewicz, M. Godlewski, Mater. Sci. Eng. B 176, 237 (2011)

59. Y. Inoue, M. Hala, A. Steigert, R. Klenk, S. Siebentritt, Optimization of buffer layer/i-layer band alignment, in 2015 IEEE 42nd Photovoltaic Specialist Conference, PVSC 2015 Institute of Electrical and Electronics Engineers Inc. (2015)

60. W. Metzger, I. Repins, M. Romero, P. Dippo, M. Contreras, R. Noufi, D. Levi, Thin Solid Films 517, 2360 (2009)

61. Y. Ando, S. Ishizuka, S. Wang, J. Chen, M.M. Islam, H. Shibata, K. Akimoto, T. Sakurai, Jpn. J. Appl. Phys. 57, 08RC08 (2018)

62. R. Scheer, H.W. Schock, Chalcogenide photovoltaics: physics, technologies, and thin film devices, (John Wiley \& Sons, Weinheim, 2011)

Cite this article as: Ramis Hertwig, Shiro Nishiwaki, Mario Ochoa, Shih-Chi Yang, Thomas Feurer, Evgeniia Gilshtein, Ayodhya N. Tiwari, Romain Carron, ALD-ZnMgO and absorber surface modifications to substitute CdS buffer layers in co-evaporated CIGSe solar cells, EPJ Photovoltaics 11, 12 (2020) 